\title{
Pemetaan Butir Soal dalam Rangka Mencapai Tujuan Pembelajaran Mata Pelajaran IPA Siswa Kelas VII Ibnu Sina SMPIT Insan Mulia Manokwari
}

\author{
Aprilyan Nur Igvianity*, Insar Damopolii, Jan Hendriek Nunaki
}

Jurusan Pendidikan Biologi FKIP Universitas Papua

*Koresponden: Aprilianzity@yahoo.com

Penelitian ini bertujuan untuk mendeskripsikan soal ujian akhir semester genap mata pelajaran IPA melalui pemetaan butir soal berdasarkan SK dan KD, mendeskripsikan validitas butir soal dan ketercapaian tujuan pembelajaran. Jenis penelitian ini adalah deskriptif kualitatif. Jumlah subyek sebanyak 29 orang siswa. Hasil analisis menunjukkan bahwa pemetaan butir soal ujian akhir semester telah tersebar menyeluruh SK dan KD, tetapi terdapat 1 SK dan KD yang memiliki soal yang lebih banyak dikarenakan soal yang diberikan berbentuk perhitungan. Hasil perhitungan validitas pada signifikan 5\% terdapat 16 butir soal yang valid dan 9 butir soal yang tidak valid. Analisis ketercapaian tujuan pembelajaran diperoleh 16 (64\%) butir soal sudah mencapai tujuan pembelajaran dan $9(36 \%)$ yang belum mencapai tujuan pembelajaran. Secara keseluruhan ketercapaian butir soal menunjukkan bahwa butir soal belum mampu mencapai tujuan pembelajaran dengan baik karena termasuk kategori cukup. 